\title{
A SUMMER WITH CHRYSOPHANUS DORCAS, KIRBY.
}

BY WILliaM W. NEWCOMB, M. D., DETROIT, MICH.

Chrysophanus dorcas is a very interesting little butterfly for several reasons : its boreal origin, in southern Michigan, confined as it is to certain detached islands or areas of decided northern character, wherein its food-plant occurs, its unworked life-history, its supposed rarity and little known distribution, all have made it an attractive field for investigation. It is also worth while to note the confusion which attaches to its identity, two other distinct species, epixanthe and helloides, having been mistaken for it.

Scattered throughout Southern Michigan, along the borders of streams, in the vicinity of lakes and in other low wet places, are numerous peat bogs, in which the vegetation is of a different type from the surrounding growth. I can here simply call attention to the existence of these northern bog areas in a region of more pronounced southern aspect. Certain boreal insects, among them Chrysophanus dorcas, occur in this latitude only in these peculiar bog habitats. ${ }^{*}$

Oakland county, one of the counties of south-eastern Michigan, is full of little lakes ranging in size from an acre or two to several square miles. It is particularly rich in the number and variety of the bog areas which it contains, and consequently many of the bog plants of the north occur abundantly. Among them there is one, the shrubby cinquefoil (Dasiphora fruticosa), with which we are particularly concerned. Doubtless the conditions necessary for the continued existence of this plant in this latitude are unusually favourable in the bogs of this county. Invariably around the pretty yellow flowers of the cinquefoil bushes at the proper time of the year, July, are to be found the little butterflies of dorcas.

The particular place where most of the observations upon this insect were made was in the Bloomfield Hills region, about twenty-four miles from Detroit. It was chosen because it was the nearest spot to the city where a goodly amount of the cinquefoil grew, and because of its accessibility. The country about is diversified by low hills and little valleys, and a small stream, a branch of the River Rouge, arising in the lakes to the westward, flows through the locality. There is considerable low, wet ground about the borders of the stream, and within half a mile to the

* See Edgar N. Transeau: The Bogs and Bog Flora of the Huron River Valley : Botanical Gazette, 40:351-375, 418-448, and $4^{1}: 17^{-42}$. On the Geographic Distribution and Ecological Relations of the Bog Plant Societies of North America ; Bot. Gaz., $36: 401-420$.

July, $\$ 909$ 
north a tamarack swamp, the trees of which are mainly small and stunted. At one point close to the little stream, covering an area of less than two acres, the cinquefoil grows very plentifully. A large portion of it is only a foot or two high, but a few clumps reach a height of three or four feet. This particular area is not a pure one, for besides the bog plants present it contains others without northern affinities. Scattered about with the cinquefoil is a good deal of the Ohio golden-rod (Solidago Ohioensis) and the white mint (Koellia Virginiana). The elevation above sea-level at Bloomfield is 834 feet, the hills in the neighbourhood some thirty odd feet higher.

During the summer of 1908 I determined to find out all I could about dorcas, especially to discover the food-plant, and if possible to rear the butterfly through all its stages. Up to this time I had not made any special effort to study it, partly because it was to be found only at some distance from the city. The late Dr. James Fletcher, who had learned of its occurrence near Detroit, and had been "specially interested in this species for several years," corresponded with me regarding it. I shall quote from his letters as his remarks bear upon the subject.

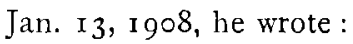

"It would be a grand thing if you could secure eggs of dorcas during the coming summer, so that we might try to breed the species. Dr. Brodie, of Toronto, assures me that this species feeds on Hypericum perforatum, but I cannot help thinking that he is mistaken. With us epixanthe flies only in peat bogs. I notice that your specimens of dorcas are labelled Bloomfield Hills. Will you please let me know the nature of the locality where you find them. Is it really on the sides of hills or is it in peat bogs near hills? It would be a great triumph if we could secure eggs and breed the species. It is not known what epixanthe feeds upon, but I have an idea that every species of Chrysophanus will eat Dock."

Again in his letter of July I I, I908, he wrote :

"With regard to getting eggs of dorcas, I would suggest your catching some females after they have passed their prime, and then tying some of these in gauze bags, both over Hypericum perforatum, which is alleged to be one of the food-plants, and also over the little Doorweed, Polygonum aviculare, upon which $C$. helloides feeds."

On July 9 I found dorcas out for the first time of the year at the Bloomfield bog. On the first and the fifth I had visited two other localities without finding any of the butterflies. I think that they were somewhat 
delayed in emerging on account of the backward season, and in a more normal year I should look for them a week or ten days earlier. As I approached the cinquefoil area I espied a female, and almost immediately a second one. I then crossed a fence into the main body of the plant, where I found the butterflies out in the largest numbers I have ever seen them. I should think there were hundreds in a space of less than two acres, perhaps even thousands, for they were everywhere flying about and alighting upon the pretty yellow flowers of the fruticosa. A few would occasionally stop on some other flower in the vicinity, but the cinquefoil flowers were evidently the favourites. The butterflies were mostly fresh, and many of them looked as if they were just out of the chrysalids. Males greatly predominated, of which I should think there might have been as many as forty to one female. I watched particularly for signs of mating. Early in' the afternoon I saw a female with three male attendants, and later on between half-past three and five I saw seven or eight females each with a male near-by, and in two instances found the male flirting his abdomen over to the female, but in no case did I observe any sexual union.

After four p.m. the butteiflies began to take up a position on the leaves of the weeds and shrubs other than the cinquefoil, with their wings outstretched flat, the upper surfaces exposed to the sun's rays, their heads as a rule directed away from the rays. As the sun settled lower, the cinquefoil flowers were less frequented, finally became deserted, and more of the butterflies were observed sunning themselves in the manner noted. Later they gradually disappeared, evidently dropping into the thick mat of vegetation, until when I left about half-past six only one or two could be seen. I located a number of females during the late afternoon by discovering that several males would cluster upon the same main upright plant stem (particularly of a species of birch), when upon closer examination a female would be found among them. The males invariably fly upward into the net when it is placed over them, the females on the contrary give a flop, landing lower down in the plant carpet. Later on I gave up the use of the net almost entirely, for I found that the butterflies were so tame that all that was needed was to place the open end of the poison tube down over them as they were seated on the cinquefoil flowers. On the wing one learns to distinguish the sexes readily by the flight alone. The males fly more quickly, hither and thither, with less directness, while the females are slower and take a straighter path. The purple colour of the male, even at several feet away, lets his sex be known; 
I made a second trip to Bloomfield on July I Ith. Females were now more in evidence, and although in several instances males were about the females, in no case did I observe any pairs in copulation. No hint of egg-laying was obtained.

Thinking that perhaps I might learn something new from other colonies of dorcas, on the $15^{\text {th I }}$ visited a spot about one mile beyond the Bloomfield bog. Dorcas appeared in good numbers, but as the extent of the cinquefoil was small, the butterflies were less in evidence than in the first location. Females were plentiful, and I observed four pairs in copulation for the first time. I did not succeed in observing a female in the act of egg-laying. About three p.m. some of the males were again seen sunning themselves.

On July I 8th I went to Rochester, Mich., walking out to the Parke, Davis \& Co. farm on Stony Creek. Here I found the largest area of the fruticosa which $\mathrm{I}$ have yet run across. The butterfies of dorcas were abundant, but the males were all worn, and many of the females, although some of the latter were still bright. Again I could not gather from the actions of any female the secret of where she laid her eggs. There was a very little Hypericum perforatum on a hillside above the cinquefoil area, but I never regarded this seriously as a food-plant, for I knew where it grew abundantly within nine miles of the city, without any hint that dorcas lived in the neighbourhood.

Dasiphora fruticosa has always seemed to me to be the most probable food-plant, for as long as I have known this butterfly (at least twenty years), I invariably found it flying in its vicinity. Accordingly, on my next visit, on July 2 Ist, to the Bloomfield bog, I confined three females over the cinquefoil, and also some over two other plants abundant there, three females over white mint, and two over Ohio golden-rod. I observed no $H$. perforatum, $P$. aviculare nor any dock growing near the fruticosa. I brought home six live female butterflies, placing them in a box near a window, with fresh stems of the cinquefoil flowers and leaves. On this trip the males that were flying were all worn, and in less numbers than the females, which were still plentiful. In the middle of the afternoon the males were again observed sunning themselves, and the habit of clustering of both sexes, as previously explained, was also noted.

On July $24^{\text {th }}$ I found eight eggs on the sprays of cinquefoil in the box with the six female butterflies. On the previous morning I had looked, but could find none. On the 3 oth I found three more eggs, and the last of these butterflies had died. 
The butterflies confined on the plants at the Bloomfield bog were examined on the $25 \mathrm{~h}$. They were all dead, and not a trace of an egg could be found on the white mint or the golden-rod, but when I looked over the cinquefoil 1 was rewarded by finding fifty-four eggs. It now seemed certain that the fruticosa was the right food-plant, and I became convinced of it when I found nine more eggs by searching on the growing plant. When I returned home ten additional eggs were discovered on some cinquefoil which had been gathered in the bog.

I now found no trouble to get eggs abundantly, both from females confined in the open and at home. In the latter case conditions were always made as attractive as possible for the butterflies; fresh Howers and leaves, with the stems kept in water, were provided in a large, light, airy box. In this way, from fourteen females confined at the same time I obtained two hundred and fifty-one eggs, an average of eighteen to each female, lacking one. A single butterfly confined alone in the same way, but in a large glass jar, laid twenty-four eggs, which, with seven eggs dissected from the abdomen after her death, gave a total of thirty-one eggs, the largest number obtained from any single female. From ten females confined in the open I secured one hundred and sixteen eggs, an average of eleven and one-half eggs, with one egg over. Of course some eggs were undoubtedly deposited before the butterflies had been taken, so that I am inclined to think that the average numher laid by a single female is not far from thirty.

I quote from Dr. Fletcher's letter of Aug. 6, 1908 :

"I don't know which I am shouting loudest, thanks to you for sending me the precious eggs of dorcas or congratulations for having found the food-plant. I must say I am surprised at this. As a piece of collateral evidence that you are right in the food-plant, Dr. Brodie reported, you remember, that he found the larvæ on Hypericum perforatum, or rather perhaps a plant which I may have understood him to mean for Hypericum perforatum. Now, there is a sufficient resemblance between that plant and Potentilla fruticosa, when described superficially, for his plant to have been that species, and where he found his eggs there is little doubt that the Potentilla grows. I am very much surprised that it should have been a Potentilla, but from your finding the eggs on the plant in the open, there is little doubt that you are right. . . . : I think it just possible that these eggs will not hatch until spring. This is the case with thoe, sometimes at any rate. . . . . It will be well for you to leave some of the eggs on the plants out of doors, where they were laid, and watch 
them in the field to see if any hatch this autumn. On one occasion when I had eggs of thö̈, several of them hatched in the autumn, and it was froin these that I got the insect through all its stages, the first time I bred it."

Again from his letter of Aug. I $9^{\text {th }}$ :

"Your success in getting these eggs is certainly remarkable. . . . I think probably that these eggs will follow the same course as those of gorgon. I remember once having from $\mathrm{Mr}$. W. H. Edwards larve to hibernate for him of $C$. Snozei, which passed the winter as half-grown larvæ. . . . . It would be very interesting if you could find eggs of dorcas in the open, and then mark the plant and watch them to see what they do linder natural conditions."

At the Bloomfield bog, on July 3 oth, there were a few worn males flying, and while females were more abundant, it was evident that dorcas was near the end of its flight for the season. On this date ten females were confined in the open. At my next visit, on August $22 \mathrm{nd}$, a rough count through the gauze bag gave me seventy-four eggs, which were left for future developments. A search on the growing cinquefoil yielded seventeen eggs, all of which except one (accidentally removed) were left on the plants. These were marked with strings, or in the case of three eggs on the same plant covered with gauze. On October isth I visited the locaiity again; the three eggs under the gauze were found on the dried leaves where the latter had fallen, and were as bright as any eggs when first laid. Two of the eggs on the plants marked with strings were also found, while no eggs at all could be located on some of the others. As the eggs are usually laid on the leaves, in the last case they had probably fallen with them to the ground. The bag in which the ten females had been confined was still in place, but on November ${ }^{5} 5^{\text {th }}$ I found that it had been removed. It was lying, however, not far off, and contained only forty-two eggs. At no time had I discovered any larvæ, and none of the eggs brought home had hatched. In a single instance I had found what looked like the base of an egg attached to a dead leaf, as if the larvæ had eaten the rest of the egg, but there was not enough of the egg to make this certain. From all the data at hand then, I concluded that dorcas passed the winter in the egg state, and that if any eggs hatched in the summer or fall it was a very small proportion, as yet undetermined.

The female butterfly under natural conditions lays her eggs near the top of the cinquefoil bush. Usually it is on the pinnate leaf, within four inches of the tip of the branch. In forty-one examinations only four eggs were lower than this, the lowest being eight inches. Most of the eggs in 
the open were found on the smaller bushes. The egy is almost always placed on the under surface of the leaflet. Out of sixty-three eggs only two were placed on the calyx, and of the other sixty-one, fifty-five, or over ninety per cent., were between the centre of the leaflet and the tip, the remainder being between the base and the centre of the leaflet. In confinement the butterfly lays her eggs on the leaves, sepals and petals, upper or lower surfaces, indiscriminately, but even here the larger number of the eggs will be located on the under surfaces of the leaflets.

An enemy of dorcas was discovered in a lemon-yellow spider. Several times I caught a spider with one of the butterflies in its grasp. In this connection I observed a peculiar thing: sitting on one of the yellow flowers was a small pale-coloured spider, probably the same as the lemoncoloured one, A butterfly was approacling the flower, when suddeniy within about a foot and a haif he gave a quick jerk, turning in another direction as if he had seen the menace to his safety in the waiting spider. His leisurely approach, abrupt turn and startled flight were at least suggestive. Once I found an egg with a circular puncture, but outside of the spider no enemy has yet been detected.

There are two or three further observations of interest. It was found that the butterflies when seated on the flowers usually held their wings upright or nearly so in the case of the males, and horizontally in the females. After a few visits with the butterflies I became able to distinguish the females when on the wing, even at some distance, not from the character of the flight, but from the shade of colour of the under side of the wings. This side is more in evidence when the insect is flying, and the feature presenting the difference of the sexes was the uniformity of the bright colour of the under side in the female. In the males there is a faint purplish tint on this surface on the hind wings and on the tips of the fore wings, lacking or feebly expressed in the females.

A peculiar disparity in the lengths of the antennæ occurred in four butterflies taken at the same place on the same day. The normal length of the antenna in the male is between 6.5 and $7 \mathrm{~mm}$., in the female about $0.5 \mathrm{~mm}$. shorter. In the male specimen taken the left antenna was of normal length, while the right measured $5.5 \mathrm{~mm}$. In two females the left antenna was normal in each, the right $4 \mathrm{~mm}$. long in one, $4.5 \mathrm{~mm}$. in the other. In the fourth specimen, a female, both antennæ were short, the left $4 \mathrm{~mm}$., the right $5 \mathrm{~mm}$. long.

When Michigan becomes better known entomologically, dorcas will undoubtedly be found over a large portion of it, both north and south, for 
its food-plant is common through most of the State. In south-eastern Michigan I know it so far only from Oakland County, although it probably occurs in the adjacent counties, but less frequently on account of the smaller number of bog areas. Dr. Wolcott* mentions $C$. epixanthe from Lamberton Lake, in western Michigan. As it was spoken of as flying over shrubby cinquefoil, I have little doubt but that the butterfly was dorcas.

The home of this species is in British North America, and it has been found in southern Labrador in the east, Sitka and Kodiak (Alaska) in the west, and in the Nahanni Mountains on the Mackenzie River (Lat. $\left.62^{\circ}\right)$, the most northerly point. It is known also from localities in between and as far south as Colorado, and colonies probably exist in many of our western cordilleras. Its most southerly limit may possibly be in Arizona, for Potentilla fruticosa has been recorded from the San Francisco Mountains in that State.

Regarding the validity of dorcas as a true species, I can best quote the emphatic words of Dr. Fletcher, to whom I sent specimens.

He wrote in his letter of Jan. I3, 1908 :

"I have no doubt at all that this is true dorcas, an insect which I have found very rare in collections. It is quite different from epixanthe. . . . I think you will see the differences at a glance. Epixanthe is of a duller gray, always pale beneath instead of ruddy fulvous, and regularly slightly smaller than dorcas. The males of dorcas always show more spots above, and have much less of the submarginal band at anal angle of secondaries above. The red markings of this submarginal band beneath are less angular than in dorcas. The two chief characteristics by which dorcas can be separated from epixanthe are the larger size and the much richer ruddy hue beneath."

In his letter of Feb. 22, 1908 :

"It is funny to me how few people really understand this species, which they mix up with helloides and epixanthe."

Again Aug. 6, Ig08:

"Few of our American entomologists believe in dorcas as a species, some thinking it to be merely helloides, and others epixanthe."

When one has these three species before him there is little doubt of the distinctness of each. The fact that the food-plants of all three are now known, and that they are different in each case, is of course significant.

*Robt, H. Wolcott : Butterflies of Grand Rapids, Mich., Can, Ent., Vol. $\mathrm{XXV}$, p. $10_{3}$. 
Florus is a variety of the female of dorcas. It occurs in Oakland county, but is much less frequent than the usual form of the female. Wm. $H$. Edwards, in describing florus, says : "Upper side dark brown, a little mottled with obscure yellow on disk of primaries at end of cell and outside the black spots in median interspaces only. . . . . . ." I find this yellow existing as a mere trace in the first median interspace to a patch of yellow outside of every black spot in the transverse row of spots on the outer third of the wings, excepting the first spot next the costa on the fore wings and the first two spots on the hind wings. The yellow at the end of the cell in my series is less frequent than the yellow outside the row of black spots. Doras males vary iittle, this being chiefly in the width of the black border on the upper surfaces of the wings.

I wish to express my appreciation of the deep interest which the late Dr. Fletcher took in my observations upon this species. It is with the greatest regret that $I$ realize $I$ an to receive no more of his instructive and enthusiastic letters. As for the full history of dorcas, I am trusting that the eggs will hatch, and that the larvæ may be raised to maturity.

\title{
NEIV GEOMETRIDS OF THE GENUS HYDRIOMENA.
}

\author{
BY L. W. SWETT, BOSTON, MASS.
}

Hydriomena Barnesata, n. sp.-Expanse, 29-35 mm.; palpi very long, $2 \mathrm{~mm}$, and beak-like, black-scaled, white-tipped, front of head gray, thorax and abdomen light gray. Fore wings ash colour, with greenish shading basally and near border of wing; hind wings smoke coloured. The fore wings have indication of a band close to body, then an ashcoloured space about $2 \mathrm{~mm}$. wide from basal band, then a black band running straight from costa to inner margin, as in most of the Hydriomenas, a greenish space, then another black band same as first, only slightly wider and more irregular in course, with a tendency to bend outward on median vein, then a greenish space and a third line running straight across same as others, only much narrower after it leaves the costa, where it starts from a large spot. These three dark, wide bands form a mesial band as it were, then from this mesial band of three straight bands is an irregular, quite wide, pale, more or less mottled space, edged externally by an irregular, narrow black line which runs from costa, where it starts from black patch running to vein 3 , where it is broken, thence to inner margin. Between this and outer margin is another black line, broad near costa, and tapering as it reaches inner margin; near apex of wing a black dash, which runs to this irregular line, as is the case in most of the July, $x 909$ 